\title{
Analisis perbedaan pengaruh kebijakan suku bunga bank sentral terhadap inflasi di Indonesia
}

\author{
Cristin Kezia*; Amril; Yohanes Vyn Amzar \\ Prodi Ekonomi Pembangunan.Fak. Ekonomi dan Binsis Universitas Jambi \\ *E-mail korespondensi: Keziasitohang96@gmail.com
}

\begin{abstract}
The purposes of this study are (1) to analyze the effect of the BI rate on inflation (2) to analyze the effect of the BI 7 day reverse repo rate on inflation (3) to analyze the different effects of the BI rate and the BI 7 day reverse repo rate on inflation. The method used in this study uses secondary data sourced from Bank Indonesia and the Central Bureau of Statistics of the Indonesian financial economy. The analysis of this study with vector autoregressive (VAR) using the Eviews 10 software program, results of the study analyzed that the difference in the influence of the central bank's interest rate policy on inflation in Indonesia, that the BI rate of interest on inflation had a positive and significant effect with a benchmark of $5 \%$ or $0.005 \%$, the analysis on the BI 7 day reverse repo rate is not significant at the benchmark of $5 \%$ or $0.005 \%$ but has a positive effect in reducing inflation in Indonesia which reflects price stability as the final target of monetary policy.
\end{abstract}

Keywords: BI rate, BI 7 day reverse repo rate, Inflation, Vector autoregressive (VAR)

\section{Abstrak}

Tujuan penelitian ini adalah (1) untuk menganalisis pengaruh BI rate terhadap Inflasi (2) untuk menganalisis pengaruh BI 7 Day reverse repo rate terhadap inflasi (3) untuk menganalisis perbedaan pengaruh antara BI rate dengan BI 7 day reverse repo rate terhadap Inflasi. Metode yang digunakan dalam penelitian ini menggunakan data sekunder yang bersumber dari Bank Indonesia dan Badan Pusat Statistik Ekonomi Keuangan Indonesia. Analisis penelitian ini dengan vector autoregressive (VAR) menggunakan perangkat lunak program Eviews 10, hasil penelitian studi menganalisis bahwa perbedaan pengaruh kebijakan suku bunga bank sentral terhadap inflasi di Indonesia, bahwa suku bunga BI rate terhadap inflasi yaitu berpengaruh positif dan signifikan dengan tolak ukur 5\% atau $0,005 \%$, analisis pada suku bunga BI 7 day reverse repo rate tidak signifikan pada tolak ukur $5 \%$ atau $0,005 \%$ tetapi berpengaruh positif dalam meredam inflasi di Indonesia yang mencerminkan stabilitas harga sebagai sasaran akhir kebijakan moneter .

Kata kunci: BI rate, BI 7 days reverse repo rate, Inflasi, Vector autoregressive (VAR)

\section{PENDAHULUAN}

Salah satu faktor fenomena makro ekonomi yang sangat menarik untuk dibahas terutama yang berkaitan dengan dampaknya yang luas terhadap agregat makro ekonomi, salah satu variabel yang mempengaruhi pergerakan prekonomian Indonesia, bahwa inflasi kecenderungan terjadinya peningkatan harga produk-produk yang beredar di masyarakat 
secara keseluruhan. Terjadinya inflasi mengakibatkan beberapa efek dalam perekonomian Pengendalian tingkat inflasi atau menjaga kestabilan harga merupakan salah satu masalah utama makroekonomi Suku bunga adalah harga dari sebuah pinjaman suku bunga mencerminkan jumlah yang dibayar oleh peminjam dan jumlah yang diterima oleh pemberi pinjaman atas tabungan mereka (Mankiw, 2006).

Suku bunga adalah pengembalian yang diberikan kepada pihak yang menempatkan sejumlah uang, Bank Indonesia mengendalikan uang yang beredar dengan dua suku bunga yaitu suku bunga sertifikat Bank Indonesia (SBI) dan suku bunga patola (Benchmark) yang disebut BI Rate. Suku bunga mulai digunakan sebagai pencapaian sasaran operasional kebijakan moneter yaitu kestabilan inflasi berdasarkan UU NO 23 Tahun 1999 (Buletin Ekonomi Moneter dan Perbankan, 2008).

Inflasi juga merupakan masalah yang dihadapi setiap perekonomian. Sampai dimana buruknya masalah ini berbeda di antara satu waktu ke waktu yang lain, dan berbeda pula dari satu Negara ke Negara lain. Tingkat inflasi yaitu presentasi kenaikan harga-harga dalam suatu tahun tertentu, biasanya digunakan sebagai ukuran untuk menunjukkan sampai dimana buruknya masalah ekonomi yang dihadapi. Pada waktu peperangan atau ketidaksetabilan politik, inflasi dapat mencapai tingkat yang lebih tinggi yang kenaikan tersebut dinamakan hiperinflasi (Sukirno, 2004).

Permasalahan pertama yang paling kritis dalam kebijakan moneter adalah kesulitan pengambil kebijakan dalam mengendalikan laju inflasi. Dalam pengertian, memang laju inflasi Indonesia relatif rendah, lebih banyak dibawah dua digit. Selain itu, inflasi yang terjadi juga sangat rentan apabila terjadi gangguan eksternal. Ketika terjadi guncangan (shock) eksternal, seperti kenaikan harga pangan, atau energi, maka secara langsung inflasi menjadi tidak terkontrol melebihi 10 persen (Brodjonegoro 2008).

Tabel 1. Data BI Rate Tahun 2014-2016 (per bulan)

\begin{tabular}{|c|c|c|c|c|c|c|}
\hline \multirow{2}{*}{ Bulan/Tahun } & \multicolumn{2}{|l|}{2014} & \multicolumn{2}{|l|}{2015} & \multicolumn{2}{|l|}{2016} \\
\hline & Jan & Des & Jan & Des & Jan & Jul \\
\hline BIR & $7,50 \%$ & $7,75 \%$ & $7,75 \%$ & $7,50 \%$ & $7,25 \%$ & $6,50 \%$ \\
\hline INF & $8,22 \%$ & $8,36 \%$ & $6,96 \%$ & $3,35 \%$ & $4,14 \%$ & $4,53 \%$ \\
\hline
\end{tabular}

Berdasarkan data pada Tabel 1 dapat diketahui bahwa suku bunga BI Rate terdiri dari data bulanan dan pada tabel ini dimulai dari Januari 2014 sampai dengan Juli 2016, pergerakan rata-rata setiap mengalami kenaikan atau penurunan perbandinan $0,25 \%$, di tahun 2014 pada bulan Januari sampai dengan bulan Desember rata-rata 7\%, di akhir tahun 2014 pada bulan Desember mengalami kenaikan sebesar 7,75\% begitu juga dengan inflasi pada Tahun 2014 rata-rata 8\% kebijakan otoritas moneter menaikan suku bunga akan meningkat.

Tahun 2015 pada bulan Januari sampai dengan bulan Desember posisi level tingkat suku bunga rata-rata tetap 7\%, pada posisi level tingkat inflasi akhir bulan Desember mengalami penurunan. Menurut Gubernur Bank Indonesia Perry Warjiyo, dalam melaksanakan kebijakan bank sentral dapat melakukan secara langsung maupun tidak langsung, jika secara langsung maksudnya bank sentral dan pemerintah secara langsung 
campur tangan dalam hal peredaran uang, sementara kebijakan moneter tidak langsung yaitu melalui pengaruh bank Sentral terhadap pemberian kredit oleh dunia perbankan, pengendalian inflasi

Beberapa studi yang melihat hubungan antara suku bunga terhadap inflasi, studi mereka menyimpulkan bahwa suku bunga berpengaruh signifikan terhadap inflasi artinya kebijakan moneter terbukti efektif dalam meredam inflasi, dengan kata lain suku bunga mempunyai pengaruh positif dan signifikan terhadap inflasi, antara lain dilakukan oleh ( Brzezina (2001), Gul dan Ekinci (2006), Andrianus dan Niko (2006), Balafif ( 2007) ).

Kebijakan moneter untuk terjaganya stabilitas di Indonesia, penggunaan suku bunga BI 7 Day Reverse Repo Rate sebagai suku bunga acuan dimulai Agustus 2016 sebelum periode tersebut suku bunga acuan menggunakan BI rate. tahun 2016 pada bulan Agustus dan bulan Desember selisih perbandingan suku bunga menurun sebesar $0,5 \%$, pada posisi inflasi perbandingan meningkat $0,23 \%$ dan di akhir Desember sebesar $4,75 \%$, di tahun 2017 pada awal bulan Januari sampai bulan Desember mengalami penurunan 0,25\% dan di akhir desember sebesar 4,25\%, terlihat pada tabel 2.

Tabel 2. Data BI 7 Day Reverse Repo Rate Tahun 2016-2019 (Per bulan)

\begin{tabular}{lllllllll}
\hline \multirow{2}{*}{ Bulan/Tahun } & $\mathbf{2 0 1 6}$ & \multicolumn{3}{c}{$\mathbf{2 0 1 7}$} & \multicolumn{2}{c}{$\mathbf{2 0 1 8}$} & \multicolumn{2}{c}{2019} \\
\cline { 2 - 9 } BI 7DRRR & Agust & Des & Jan & Des & Jan & Des & Jan & Feb \\
INF & $5,25 \%$ & $4,75 \%$ & $4,75 \%$ & $4,25 \%$ & $4,25 \%$ & $6,00 \%$ & $6,00 \%$ & $6,00 \%$ \\
\multicolumn{2}{l}{ Sumber: Bank Indonesia, 2019 (diolah) } & & & & & &
\end{tabular}

Berdasarkan Tabel 2 kondisi inflasi rata-rata 3\%. Tahun 2018 dan tahun 2019 suku bunga BI 7 Day Reverse Repo Rate meningkat sampai dengan 6,00\%, perbandingan antara bulan Januari dan bulan Desember tingkat suku bunga sebesar $1,75 \%$, pada posisi tingkat inflasi berada posisi level 3\%, dan di tahun 2019 suku bunga bertahan pada posisi level $6,00 \%$, perubahan pada inflasi menjadi menurun sebesar $2 \%$ dari rata-rata inflasi tahun sebelumnya yaitu $3 \%$.

\section{METODE}

\section{Jenis dan sumber data}

Data yang digunakan dalam penelitian ini adalah data data sekunder. Data sekunder merupakan data yang dikumpulkan dari sumber lain yang berkaitan dengan penelitian ini. Berdasarkan kajian beberapa literatur penelitian ini akan menggunakan data sekunder. Data-data tersebut berupa data bulanan dalam rentang waktu (time series). Adapun data sekunder yang digunakan adalah data BI Rate pada Januari 2014- Juli 2016, BI 7 Day Repo Rate pada Agustus 2016- Februari 2019. Sumber data yang digunakan dalam penelitian ini dengan cara mengumpulkan data yang disediakan oleh instansi yang bersangkutanAdapun instansi yang bersangkutan dalam penelitian ini adalah Bank Indonesia dan Badan Pusat Statistik Indonesia

\section{Metode analisis data}

Metode yang akan digunakan dalam menganalisa data yang sudah ada, analisisnya menggunakan metode kuantitatif, yakni metode analisis yang menggunakan alat kuantitatif. alat analisis yang digunakan dalam penelitian ini adalah VAR (Vector Autoregressive) 
menggunakan metode analisis yang diperoleh dari Bank Indonesia dan beberapa sumber lain. Alat analisis VAR (Vector Autoregressive). Dalam analisis VAR digunakan untuk system variabel-variabel runtut waktu dan untuk menganalisis, mempertimbangkan beberapa variabel endogen secara bersama-sama dalam suatu model.

\section{HASIL DAN PEMBAHASAN}

\section{Inflasi}

Bank Indonesia sebagai otoritas moneter memiliki satu tujuan tunggal yaitu menjaga dan memelihara kestabilan nilai tukar rupiah, yang salah satunya dilihat melalui inflasiTahun 2014 pada bulan Januari sebesar 8,22\% dan pada bulan Desember 2014 sebesar $8,36 \%$ berdasarkan data yang diperoleh bahwa sepanjang tahun 2014 mengalami kenaikan inflasi, bulan Desember 2014 meningkat tinggi dan sedikit melebihi perkiraan Bank Indonesia. Sepanjang tahun 2014 inflasi paling menurun pada bulan Agustus sebesar 3,99\%. Realisasi inflasi tersebut sedikit lebih tinggi dari perkiraan Bank Indonesia, terutama karena lebih tingginya inflasi kelompok volatile food. Ditengah meningkatnya inflasi dari sisi biaya (cost push) akibat kenaikan harga komoditas yang diatur pemerintah dan gejolak harga pangan Capaian ini tidak terlepas dari peran kebijakan Bank Indonesia dalam mengelola permintaan domestik, menjaga stabilitas nilai tukar, dan mengarahkan ekspektasi inflasi. Perkembangan tingkat inflasi dapat dilihat pada grafik 1.

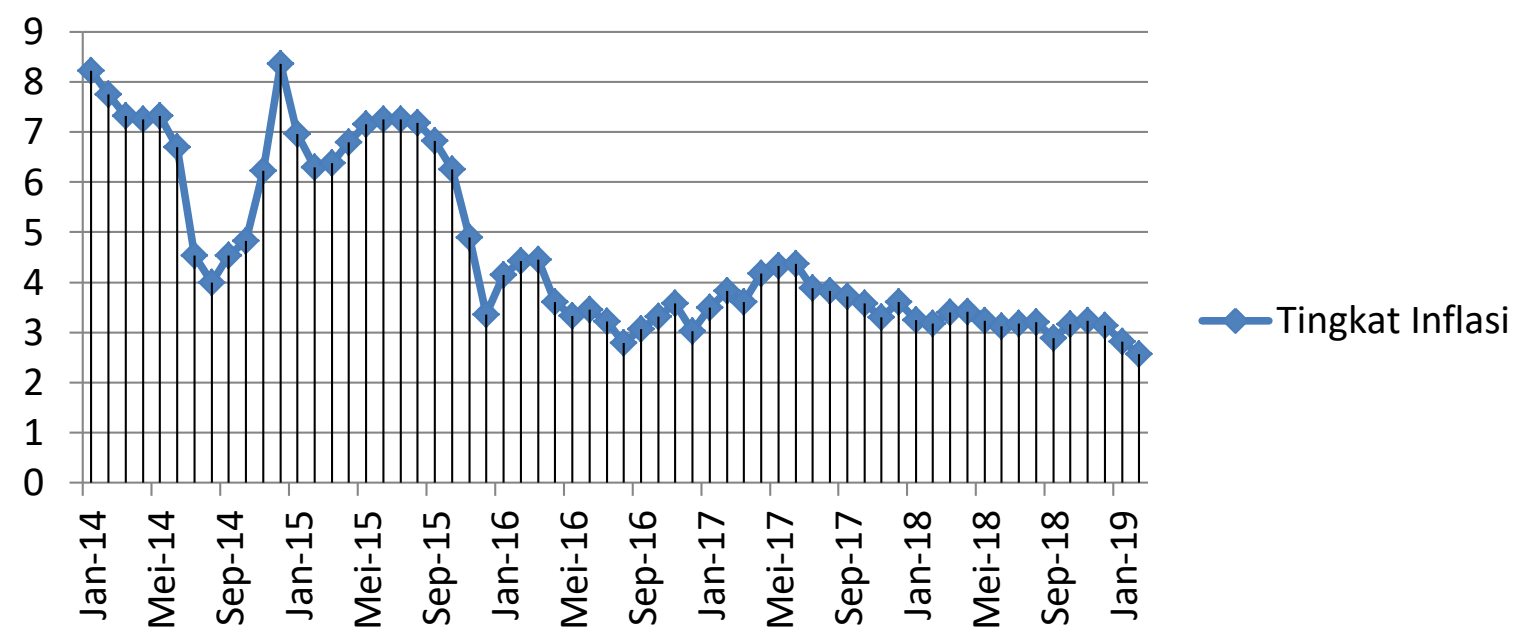

Sumber: Statistik Ekonomi Keuangan Indonesia, 2019

Gambar 1. Tingkat Inflasi Indonesia

Berdsarkan Gambar 1 tahun 2018 ke tahun 2019 pada bulan Januari 2018 sebesar 3,25\% sampai Januari 2019 menurun menjadi 2,82\% dan mengalami perubahan pada bulan Februari 2019 2,57\% dari pada bulan Februari di tahun 2019 sebesar 3,18\%. Target atau sasaran inflasi merupakan tingkat inflasi yang harus dicapai oleh Bank Indonesia, berkoordinasi dengan pemerintah. Penetapan sasaran inflasi berdasarkan UU mengenai Bank Indonesia dilakukan oleh pemerintah. sasaran inflasi ditetapkan untuk tiga tahun ke depan melalui Peraturan Menteri Keuangan (PMK). Bank Indonesia dan Pemerintah senantiasa berkomitmen untuk mencapai sasaran inflasi yang ditetapkan tersebut melalui koordinasi kebijakan yang konsisten dengan sasaran inflasi tersebut. 


\section{$B I$ rate}

Sebelas tahun lalu, tepatnya 5 Juli 2005, suku bunga acuan BI Rate diperkenalkan dan digunakan untuk pertama kalinya. Melalui BI Rate diharapkan kebijakan moneter lebih transparan, akuntabel, dan mudah dimengerti oleh masyarakat. Tentu saja juga lebih efektif dalam mempengaruhi ekspektasi inflasi masyarakat. BI Rate merupakan suku bunga dengan tenor ekuivalen 9 sampai 12 bulan yang berfungsi sebagai sinyal kebijakan moneter. Tahun 2014 bulan Januari sebesar 7,50\%, sampai pada bulan Desember sebesar $7,75 \%$, dari bulan januari sampai Oktober memiliki tingkat suku bunga yang sama sebesar $7,50 \%$, pada bulan November juga bulan Desember memiliki tingkat suku bunga yang sama naik $0,05 \%$ menjadi $7,75 \%$.

Rapat Dewan Gubernur (RDG) Bank Indonesia pada 9 Januari 2014 memutuskan untuk mempertahankan BI Rate sebesar 7,50\%, dengan suku bunga Lending Facility dan suku bunga Deposit Facility masing-masing tetap pada level 7,50\% dan 5,75\%. Evaluasi menyeluruh ekonomi tahun 2013 dan prospek ekonomi tahun 2014-2015 menunjukkan kebijakan ini masih konsisten dengan upaya mengarahkan inflasi menuju ke sasaran $4,5 \pm 1 \%$ pada 2014 dan $4 \pm 1 \%$ pada 2015, serta mengendalikan penyesuaian ekonomi Indonesia sehingga defisit transaksi berjalan menurun ke tingkat yang lebih sehat. Bank Indonesia juga akan terus memperkuat bauran kebijakan moneter dan makro prudensial, serta mempererat koordinasi dengan Pemerintah dalam pengendalian inflasi dan defisit transaksi berjalan. Perkembangan BI Rate dapat dilihat pada grafik 2.

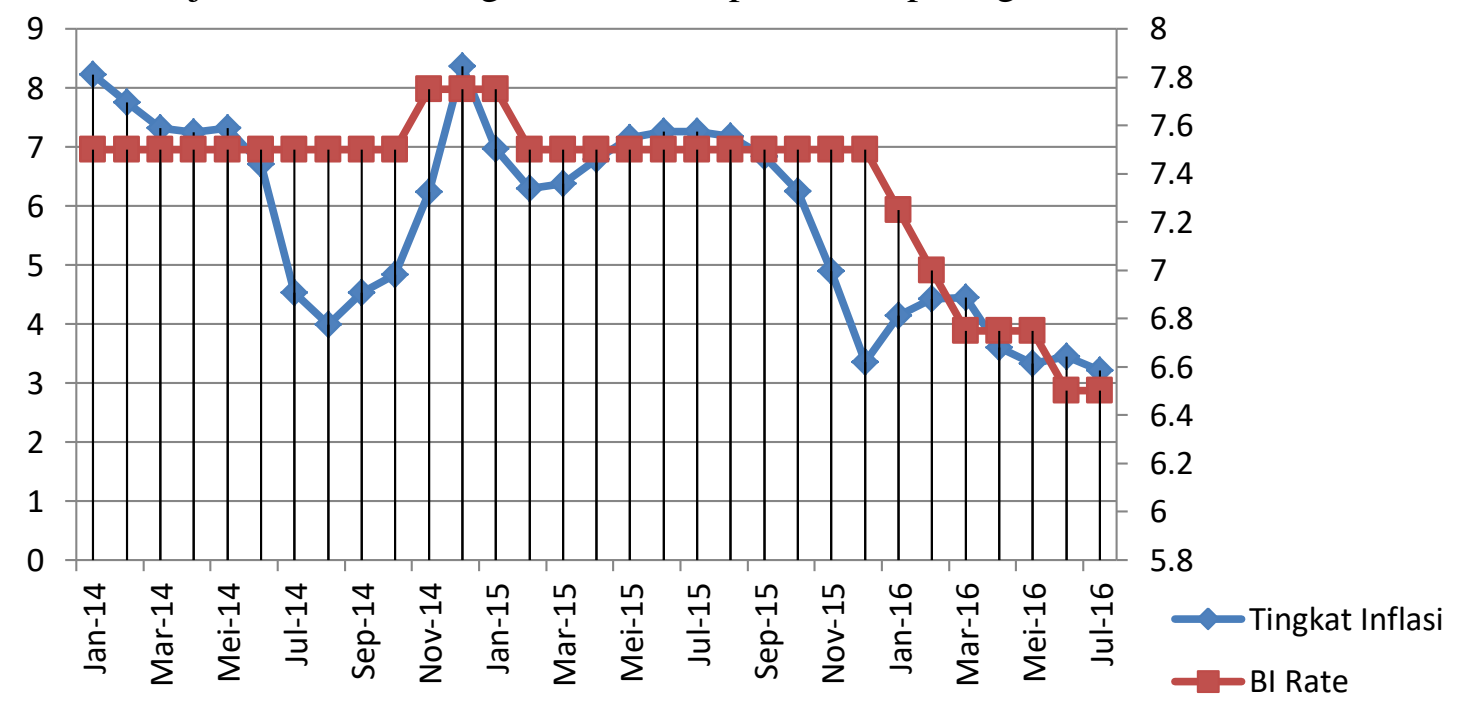

Sumber: Bank Indonesia, 2019.

\section{Gambar 2. BI Rate}

Tahun 2015 Suku bunga BI Rate pada bulan Januari sebesar 7,75\% dan Bulan Februari hingga bulan Desember menurun seperti awal bulan ditahun 2014, sebesar 7,50\%. Rapat Dewan Gubernur (RDG) Bank Indonesia pada 17 Desember 2015 memutuskan untuk mempertahankan BI Rate sebesar 7,50\%, dengan suku bunga Deposit Facility 5,50\% dan Lending Facility pada level 8,00\%. Bank Indonesia memandang bahwa ruang bagi pelonggaran kebijakan moneter semakin terbuka dengan terjaganya stabilitas makro ekonomi, khususnya inflasi akhir tahun 2015 yang akan berada di bawah 3\% dan defisit transaksi berjalan yang akan berada pada kisaran $2 \%$ dari Produk Domestik Bruto (PDB). 
Tahun 2016 bulan Januari suku bunga BI Rate sebesar 7,25\%. Rapat Dewan Gubernur (RDG) Bank Indonesia pada 14-15 Desember 2016 memutuskan untuk mempertahankan BI 7-day Reverse Repo Rate (BI 7-day RR Rate) tetap sebesar 4,75\%, dengan suku bunga Deposit Facility tetap sebesar 4,00\% dan Lending Facility tetap sebesar 5,50\%, berlaku efektif sejak 16 Desember 2016. Kebijakan tersebut konsisten dengan upaya mengoptimalkan pemulihan ekonomi domestik dengan tetap menjaga stabilitas makro ekonomi dan sistem keuangan, di tengah ketidakpastian pasar keuangan global.

\section{BI 7 day reverse repo rate}

Tahun 2017 Rapat Dewan Gubernur (RDG) Bank Indonesia pada 17-18 Mei memutuskan untuk mempertahankan BI 7-day Reverse Repo Rate (BI 7-day RR Rate) tetap sebesar 4,75\%, dengan suku bunga Deposit Facility tetap sebesar 4,00\% dan Lending Facility tetap sebesar 5,50\%, berlaku efektif sejak 19 Mei 2017. Keputusan tersebut konsisten dengan upaya Bank Indonesia menjaga stabilitas makro ekonomi dan sistem keuangan dengan tetap mendorong proses pemulihan perekonomian domestik. Bank Indonesia tetap mewaspadai sejumlah risiko, baik yang bersumber dari global maupun domestik. Tahun 2018 di awal bulan Januari sebesar 4,25\% sampai bulan Mei, dan mengalami kenaikan peningkatan sampai bulan Desember sebesar 6,00\%, dan di Tahun 2019 Rapat Dewan Gubernur (RDG) Bank Indonesia pada 24-25 April2019 memutuskan untuk mempertahankan BI 7-day Reverse Repo Rate (BI7DRR) sebesar 6,00\%, suku bunga Deposit Facility sebesar 5,25\%, dan suku bunga Lending Facility sebesar 6,75\%. Perkembangan BI 7 day RR Rate terlihat di grafik 3.

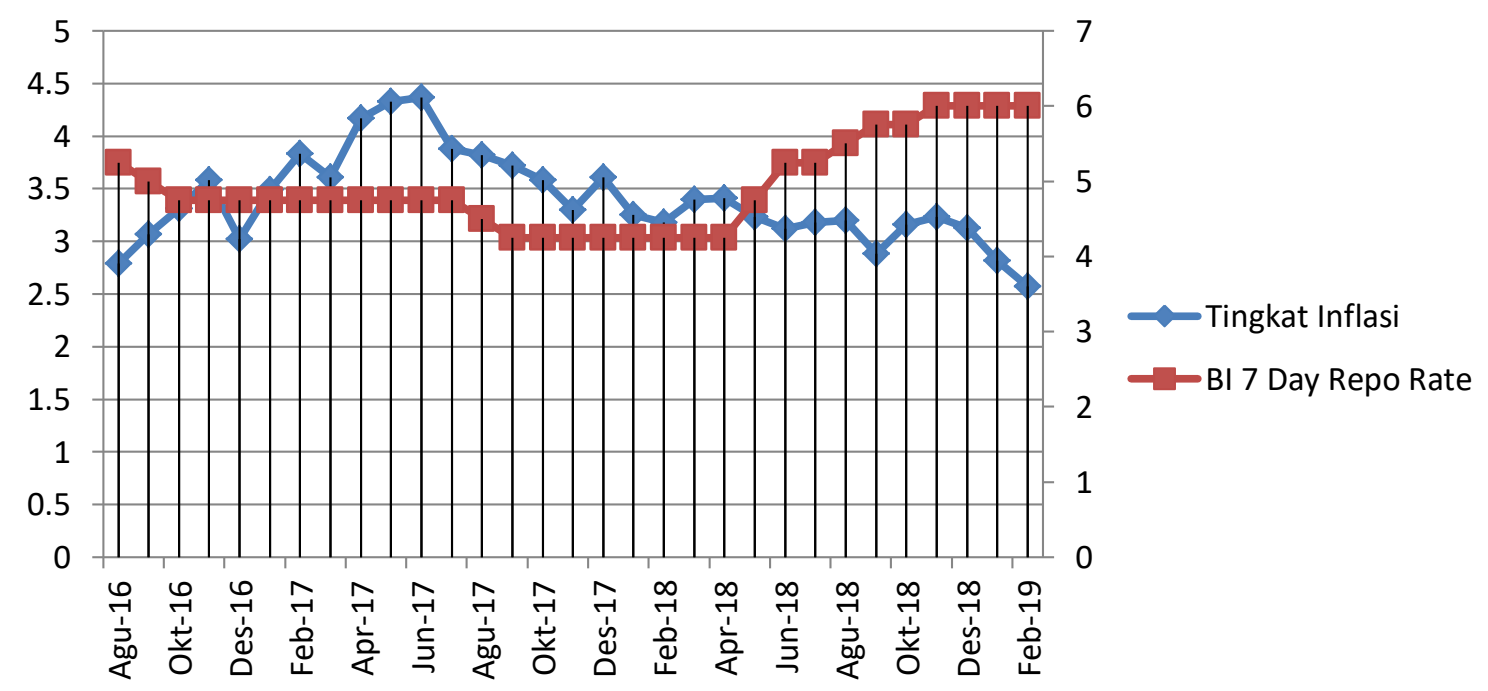

Sumber: Bank Indonesia, 2019.

Gambar 3. BI 7 day reverse repo rate

Bank Indonesia melakukan penguatan kerangka operasi moneter dengan mengimplementasikan suku bunga acuan atau suku bunga kebijakan baru yaitu BI 7-Day (Reverse) Repo Rate, yang berlaku efektif sejak 19 Agustus 2016, menggantikan BI Rate. Kerangka operasi moneter senantiasa disempurnakan untuk memperkuat efektivitas kebijakan dalam mencapai sasaran inflasi yang ditetapkan. Instrumen BI 7-day 
(Reverse) Repo Rate digunakan sebagai suku bunga kebijakan baru karena dapat secara cepat memengaruhi pasar uang.

\section{Estimasi VAR pengaruh bi rate terhadap inflasi}

VAR memiliki instrument spesifik yang memiliki fungsi spesifik dalam menjelaskan interaksi antar variabel dalam model. Instrument itu meliputi Impulse Response Function (IRF)dan forecast Error variance

Tabel 3. Estimasi VAR BI rate dan inflasi:

\begin{tabular}{lrr}
\hline \multicolumn{1}{c}{ VARIABEL } & \multicolumn{1}{c}{ BIR } & INF \\
\hline BIR $(-1)$ & 0.328495 & 4.707629 \\
& $(0.21906)$ & $(2.16896)$ \\
BIR $(-2)$ & {$[1.49957]$} & {$[2,17045]$} \\
& -0.039891 & -2.626386 \\
& $(0.23115)$ & $(2.28867)$ \\
INF $(-1)$ & {$[-0.17258]$} & {$[-1.14756]$} \\
& 0.025367 & 0.138064 \\
& $(0.02174)$ & $(0.25821)$ \\
INF $(-2)$ & {$[1.16677]$} & {$[-1.59027]$} \\
& -0.004774 & -0.410621 \\
C & $(0.02608)$ & $(0.25821)$ \\
& {$[-0.18307]$} & {$[-1.59027]$} \\
& -0.024933 & -0.083755 \\
& $(0.02313)$ & $(0.22902)$ \\
Sum & {$[-1.07795]$} & {$[-0.36571)$} \\
\hline
\end{tabular}

Sumber: Data diolah, 2019.

Berdasarkan hasil estimasi tabel 3 menunjukan bahwa variabel yang memiliki hubungan yang signifikan terhadap BI Rate dibuktikkan dengan nilai t-statistik variabel BI Rate SERBIR $(-1)>$ t-tabel dalam penelitian ini $5 \%$ atau $0,05 \%$. Nilai t-statistik variabel SERBIR adalah [2.17045]. Hasil $\mathrm{R}^{2}$ adalah sebesar 0.122689, cara menentukan variabel depended dilihat dari R-Squared terbesar variabel.

\section{Uji stasionaritas/ uji akar unit}

Uji stasioneritas berdasarkan uji Dickey-Fuller diperoleh data yang belum stasioner pada data. Dengan demikian melalui differencing pertama (first difference).

Tabel 4 Uji stasionaritas / uji akar unit

\begin{tabular}{lcccccc}
\hline \multirow{2}{*}{ Variabel } & \multicolumn{6}{c}{ Uji akar unit / uji stasionaritas } \\
\cline { 2 - 7 } & \multicolumn{2}{c}{ Level } & \multicolumn{2}{c}{ 1st Difference } & \multicolumn{2}{c}{ 2nd Difference } \\
\cline { 2 - 7 } & ADF & Prob & ADF & Prob & ADF & Prob \\
\hline BI Rate & 1.122030 & 0.9968 & -3.957272 & 0.0051 & 7.433751 & 0.0000 \\
\hline
\end{tabular}

Sumber: Data diolah, 2019 
Berdasarkan hasil uji akar unit/uji stasionaritas pada tabel 4 tingkat level tidak signifikan karena tidak memenuhi syarat dan melebihi $\alpha=5 \%$ pada tingkat First Different mengalami signifikan, tetapi pada Second Different lebih baik hasil. Probabilitasnya dari tingkat First Difference yaitu sebesar 0,000 dinyatakan stasioner.

\section{Uji penentuan panjang lag optimal}

Estimasi dengan VAR mensyaratkan data dalam kondisi stasioner. Oleh karena data variabel sudah stasioner pada pada tingkat Second Difference. Estimasi model VAR dimulai dengan menentukan berapa panjang lag yang tepat dalam model VAR, di Uji Panjang Lag Optimal, dapat menentukan panjang lag optimal melalui banyaknya bintang pada periode tersebut pada Variabel BI Rate.

Tabel 5. Hasil pengujian lag optimal

\begin{tabular}{lllllll}
\hline & \multicolumn{6}{c}{ Metode pengujian } \\
\cline { 2 - 7 } Lag & LogL & \multicolumn{1}{c}{ LR } & \multicolumn{1}{c}{ FPE } & \multicolumn{1}{c}{ AIC } & SC & HQ \\
\hline 0 & -21.04641 & NA $^{*}$ & $0.017783^{*}$ & 1.646172 & $1.741330^{*}$ & $1.675263^{*}$ \\
1 & -17.04455 & 7.146193 & 0.017809 & $1.646039^{*}$ & 1.931511 & 1.733311 \\
2 & -14.51605 & 4.153963 & 0.019903 & 1.751146 & 2.226924 & 1.896599 \\
\hline
\end{tabular}

Sumber: Data diolah, 2019

Tabel 5 menunjukkan bahwa lag 1 adalah lag yang paling optimal. Hal ini berdasarkan pada pertimbangan bahwa lag 1 direkomendasikan oleh metode pengujian yaitu LR, FPE, AIC, HQ ditunjukkan dengan tanda bintang (*) yang menunjukkan lag optimal. Pada Uji lag dalam penelitian ini, dimana lag dengan nilai AIC terendah adalah yang paling optimal. Untuk penelitian ini maka pengujian lag akan dilakukan 0 sampai 2. Lag dengan nilai AIC terendah inilah Lag yang paling Optimal.sehingga lag tersebut yang akan digunakan dalam pengujian selanjuutnya

\section{Uji kausalitas granger (granger's causality test)}

Uji kausalitas dilakukan untuk mengetahui apakah suatu variabel endogen dapat diperlakukan sebagai variabel eksogen. Hal ini bermula dari ketidaktahuan keterpengaruhan antar variabel. Jika ada dua variabel y dan $\mathrm{z}$, maka apakah y menyebabkan $\mathrm{z}$ atau $\mathrm{z}$ menyebabkan y atau berlaku keduanya atau tidak ada hubungan keduanya.

Tabel 6. Uji kasaulitas granger

\begin{tabular}{lllll}
\hline Null Hypothesis (H0) & Probabilitas & Hasil Pengujian & Hubungan Kausalitas \\
\hline SERINF does not & 0,2580 & Tidak & Cukup & Hubungan tidak se arah \\
Granger Cause SERBIR & & Bukti Menolak & dari SERINF ke SERBIR \\
SERBIR does not & 0,0432 & H0 & Hubungan 1 arah dari \\
Granger Cause SERINF & & Tolak H0 & SERBIR ke SERINF \\
\cline { 3 - 5 }
\end{tabular}

Sumber: Data diolah, 2019

Penelitian ini mengguakan metode Granger's Causality. Granger's Causality digunakan untuk menguji adanya hubungan kausalitas antara dua variabel. Kekuatan 
prediksi (predictive power) dari informasi sebelumnya dapat menunjukkan adanya hubungan kausalitas antara y dan z dalam jangka waktu lama. Gejolak dari variabel BI Rate dapat dilihat di table 7

Tabel 6. Hasil uji variance decomposition

\begin{tabular}{rrr}
\hline S.E. & BIR & INF \\
\hline-0.1138 & -100 & 0 \\
1.12638 & 12.7326 & 87.2674 \\
-0.12 & -95.05 & -4.9503 \\
1.233 & 25.7843 & 74.2157 \\
-0.1216 & -94.809 & -5.1907 \\
1.26726 & 24.6367 & 75.3633 \\
-0.1219 & -94.539 & -5.461 \\
1.28606 & 25.7336 & 74.2664 \\
-0.122 & -94.416 & -5.5835 \\
1.2893 & 25.9645 & 74.0355 \\
-0.122 & -94.416 & -5.5837 \\
1.29096 & 25.9531 & 74.0469 \\
-0.1221 & -94.399 & -5.6005 \\
1.29142 & 26.0048 & 73.9953 \\
-0.1221 & -94.399 & -5.6008 \\
1.29154 & 26.0001 & 73.9999 \\
$(0,1220060)$ & -94.398 & -5.6019 \\
1.29159 & 26.0043 & 73.9957 \\
-0.1221 & -94.398 & -5.6022 \\
1.2916 & 26.0047 & 73.9953 \\
\hline
\end{tabular}

Sumber: Data diolah, 2019

Tabel 6 menunjukkan bahwa perkiraan error variance pada periode pertama seluruhnya 100\% dijelaskan oleh BI Rate sedangkan variabel inflasi tidak brpengaruh, setiap periodenya masing-masing variabel memberikan kontribusi kepada BI Rate hingga periode ke 10. Berdasarkan nilai Error variance dapat disimpulkan bahwa perubahan BI Rate lebih banyak dipengaruhi oleh inflasi, analisis Variance Decomposition ini menggambarkan relatif pentingnya setiap variabel di dalam sistem VAR karena adanya seberapa kuat komposisi dari peranan variabel tertentu terhadap lainnya Variance Decomposition.

\section{Pengaruh BI 7 day reverse repo rate dan bi rate terhadap inflasi}

Vector Auto Regression (VAR) digunakan untuk memproyeksikan sebuah system dengan variabel runtut waktu dan untuk menganalisis dampak dinamis dari faktor gangguan yang terdapat dalam sistem variabel tersebut. Analisis VAR sama dengan suatu model persamaan simultan, karena dalam Analisis VAR kita mempertimbangkan beberapa variabel endogen secara bersama-sama 
Tabel 7. Estimasi VAR BI 7 days reverse repo rate dan inflasi

\begin{tabular}{|c|c|c|}
\hline & BI7DRRR & INF \\
\hline \multirow[t]{3}{*}{ BI7DRRR (-1) } & 0.66568 & -0.029861 \\
\hline & $(0.20069)$ & $(0.26605)$ \\
\hline & {$[0.33170]$} & {$[-0.11224]$} \\
\hline \multirow{3}{*}{ BI7DRRR (-2) } & 0.207160 & 0.134937 \\
\hline & $(0.19751)$ & $(0.26184)$ \\
\hline & [1.04888] & {$[0.51535]$} \\
\hline \multirow[t]{3}{*}{$\operatorname{INF}(-1)$} & 0.137712 & -0.206045 \\
\hline & $(0.15834)$ & $(0.20992)$ \\
\hline & {$[0.86630]$} & {$[-0.98156]$} \\
\hline \multirow[t]{3}{*}{$\operatorname{INF}(-2)$} & 0.45678 & -0.074972 \\
\hline & $(0.16214)$ & $(0.21495)$ \\
\hline & {$[0.28172]$} & {$[-0.34878]$} \\
\hline \multirow[t]{4}{*}{$\mathrm{C}$} & 0.037387 & -0.029906 \\
\hline & $(0.04331)$ & $(0.05742)$ \\
\hline & {$[0.86318]$} & {$[-0.52082]$} \\
\hline & BI7DRRR & INF \\
\hline \multirow[t]{3}{*}{ BI7DRRR (-1) } & 0.66568 & -0.029861 \\
\hline & $(0.20069)$ & $(0.26605)$ \\
\hline & {$[0.33170]$} & {$[-0.11224]$} \\
\hline \multirow[t]{3}{*}{ BI7DRRR (-2) } & 0.207160 & 0.134937 \\
\hline & $(0.19751)$ & $(0.26184)$ \\
\hline & [1.04888] & {$[0.51535]$} \\
\hline \multirow{3}{*}{$\operatorname{INF}(-1)$} & 0.137712 & -0.206045 \\
\hline & $(0.15834)$ & $(0.20992)$ \\
\hline & {$[0.86630]$} & {$[-0.98156]$} \\
\hline \multirow[t]{3}{*}{$\operatorname{INF}(-2)$} & 0.45678 & -0.074972 \\
\hline & $(0.16214)$ & $(0.21495)$ \\
\hline & {$[0.28172]$} & {$[-0.34878]$} \\
\hline \multirow[t]{3}{*}{$\mathrm{C}$} & 0.037387 & -0.029906 \\
\hline & $(0.04331)$ & $(0.05742)$ \\
\hline & {$[0.86318]$} & {$[-0.52082]$} \\
\hline
\end{tabular}

Sumber: Data diolah, 2019

Berdasarka hasil rgresi model VAR maka diporeh mpoel VAR yaitu sebagai berikut;

$\mathrm{X} 1, t=\mathrm{a} 1,1+\sum_{1,1=1}^{k} a 1,1 \quad \mathrm{X}_{1}, t-1+\sum_{1,2=1}^{k} b 1,2 \quad \mathrm{X}_{2}, t-2+\sum_{1,3=1}^{k} c 1,3 \quad \mathrm{X}_{3}, t-1 \sum_{1,4=1}^{k} c 1,4 \quad \mathrm{X}_{4}, t-2 \quad 1$ $+\sum_{1,5=1}^{k} c 1,5 \mathrm{X}_{5}, t-2$

$\mathrm{X} 2, t=\mathrm{a} 2,1+\sum_{2,1=1}^{k} a 2,1 \quad \mathrm{X}_{1}, t-1+\sum_{2,2=1}^{k} b 2,2 \quad \mathrm{X}_{2, t} t-2+\sum_{2,3=1}^{k} c 2,3 \quad \mathrm{X}_{3}, t-1 \quad \sum_{2,4=1}^{k} d 2,4 \quad \mathrm{X}_{4}, t-2+$ $\sum_{2,5=1}^{k} d 2,5$

$\mathrm{X} 1, t=\mathrm{a} 1,1+\sum_{1,1=1}^{k} a 1,1 \quad \mathrm{X}_{1}, t-1+\sum_{1,2=1}^{k} b 1,2 \quad \mathrm{X}_{2, t}, 2+\sum_{1,3=1}^{k} c 1,3 \quad \mathrm{X}_{3}, t 1+\sum_{1,4=1}^{k} d 1,4 \quad \mathrm{X}_{4, t}$ $2+\sum_{1,5=1}^{k} e 1,5$

$\mathrm{X} 2, t=\mathrm{a} 2,1+\sum_{2,1=1}^{k} a 2, i \quad \mathrm{X}_{1, t} t-1+\sum_{2,2=1}^{k} b 2,2 \quad \mathrm{X}_{2, t}, 2+\sum_{2,3=1}^{k} c 2,3 \quad \mathrm{X}_{3}, t-1+\sum_{2,4=1}^{k} d 2,4 \quad \mathrm{X}_{4, t}-2$

$+\sum_{2,5=1}^{k} e 2,5$ 
Hasil Uji Stasionaritas, pada tingkat Level tidak signifikan karena > 5\%, Variabel BI 7 Day Reverse Repo Rate memiliki hasil yang stasioner pada tingkat first different.

Tabel 8. Uji akar unit / uji stasionaritas

\begin{tabular}{cllllll}
\hline \multirow{2}{*}{ Variabel } & \multicolumn{4}{l}{ Uji Akar Unit / Uji } & \multicolumn{3}{l}{ Stasionaritas } \\
\cline { 2 - 7 } & Level & \multicolumn{3}{l}{ 1st Difference } & \multicolumn{2}{l}{ 2nd Difference } \\
\cline { 2 - 7 } & ADF & Prob & ADF & Prob & ADF & Prob \\
\hline BI 7 Day RRR & 0.2112246 & 0.9266 & -4.768123 & 0.0006 & 6.418291 & 0.0000 \\
\hline
\end{tabular}

Sumber: Data diolah, 2019

Hasil uji stasionaritas second different memiliki hasil yang signifikant yaitu sebesar 0,0000 , untuk menguji stasionaritas tiap variabel pada $\alpha=5 \%$ jika probabilitas lebih kecil dibandingkan $\alpha=5 \%$ maka tolak $\mathrm{H} 0$ atau berarti tidak ada unit root (Stasioner).

\section{Uji penentuan panjang lag optimal}

Uji Lag optimal digunakan untuk menentukan panjang lag yang optimal. Secara umum terdapat beberapa metode dalam menentukan lag, diantaranya adalah Final Prediction Error (FPE), Akaike Information Criterion (AIC), Schwarz information Criterion (SIC), dan Hannan-Quinn information criterion (HIC). Berikut hasil uji yang telah dilakukan.

Tabel 9. Hasil uji panjang lag optimal

\begin{tabular}{clccccc}
\hline \multicolumn{7}{c}{ Metode Pengujian } \\
\hline LogL & \multicolumn{1}{c}{ LR } & FPE & AIC & SC & HQ \\
\hline 0.215961 & NA* $^{*}$ & $0.003894 *$ & $0.127431^{*}$ & $0.222589^{*}$ & $0.156522^{*}$ \\
1.072744 & 7.146193 & 0.004882 & 0.351947 & 0.637419 & 0.439219 \\
2.169875 & 4.153969 & 0.006044 & 0.559295 & 1.035082 & 0.704748 \\
\cline { 5 - 6 }
\end{tabular}

Sumber: Data diolah, 2019

Tabel 9 menunjukkan bahwa lag 0 adalah lag yang paling optimal. Hal ini berdasarkan pada pertimbangan bahwa lag 0 direkomendasikan oleh metode pengujian yaitu LR, FPE, AIC, HQ ditunjukkan dengan tanda bintang $(*)$ yang menunjukkan lag optimal. Pada Uji lag dalam penelitian ini, dimana lag dengan nilai AIC terendah adalah yang paling optimal.

\section{Uji kausalitas granger (granger's causality test)}

Pengujian dengan Granger Causality dimaksudkan hanya untuk menguji hubungan diantara variabel dan bukan untuk melakukan estimasi. Hasil pengujian ini akan menunjukkan ada tidaknya hubungan kausalitas. 
Tabel 10. Uji kasaulitas granger

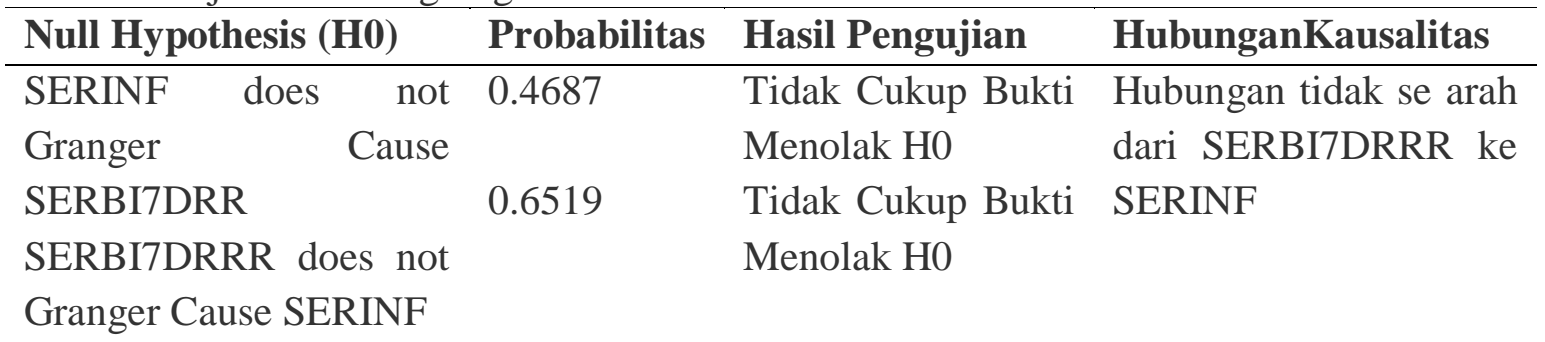

Sumber: Data diolah, 2019

Berdasarkan tabel 10 instrumen bi 7 BI DRR digunakan sebagai suku bunga kebijakan baru karena dapat secara cepat memengaruhi pasar uang, perbankan. Bahwa hubungan tidak ada kausalitas pada BI 7 DRRR terhadap inflasi, dikarenakan probabilitas melebihi syarat penetapan 5\% atau 0,005 dengan begitu hasil pengujian tidak cukup bukti menolak H0.

Tabel 11. Hasil uji variance decomposition

\begin{tabular}{rrr}
\hline \multicolumn{4}{c}{ Variance Decomposition of BI 7 Day Reverse Repo Rate \& Inflasi } \\
\hline S.E. & BI7DRRR & INF \\
\hline$(0.224700)$ & $(100.0000)$ & $(0.000000)$ \\
0.297889 & 2.884998 & 97.11500 \\
$(0.228420)$ & $(96.89220)$ & $(3.107804)$ \\
0.303990 & 2.785286 & 97.21471 \\
$(0.232996)$ & $(96.90119)$ & $(3.098814)$ \\
0.305977 & 3.920099 & 96.07990 \\
$(0.233230)$ & $(96.86813)$ & $(3.131874)$ \\
0.306299 & 3.969769 & 96.03023 \\
$(0.233487)$ & $(96.85772)$ & $(3.142284)$ \\
0.306338 & 3.993978 & 96.00602 \\
$(0.233512)$ & $(96.85364)$ & $(3.146357)$ \\
0.306339 & 3.994235 & 96.00577 \\
$(0.233528)$ & $(96.85323)$ & $(3.146768)$ \\
0.306340 & 3.994983 & 96.00502 \\
$(0.233530)$ & $(96.85295)$ & $(3.147050)$ \\
0.306340 & 3.994994 & 96.00501 \\
$(0.233531)$ & $(96.85290)$ & $(3.147100)$ \\
0.306340 & 3.995056 & 96.00494 \\
$(0.233531)$ & $(96.85288)$ & $(3.147117)$ \\
0.306340 & 3.995058 & 96.00494 \\
\hline
\end{tabular}

Sumber: Data diolah, 2019

Tabel 11 menunjukkan analisis variance decomposition pada BI 7DRRR menujukan bergejolak menunjukkan bahwa perkiraan error variance pada periode pertama seluruhnya 
100\% dijelaskan oleh BI7DRRR sedangkan variabel inflasi berpengaruh hingga periode ke 10. Berdasarkan nilai Error variance dan dapat disimpulkan bahwa perubahan BI7DRRR tidak mempengaruhi inflasi..

\section{Implikasi hasil penelitian}

Hasil dari penelitian ini bahwa variabel BI Rate pada uji stasionaritas mengalami signifikan dan pada uji panjang lag optimal, BI Rate memiliki uji lag optimal signifikan tetapi jika dibandingkan dengan AIC, BIR dengan BI 7 DRRR yaitu lebih Optimal BI 7 DRRR dengan tanda bintang sehingga dalam variabel ini, lebih signifikan dengan AIC Terendah Pada Uji Kausalitas Granger BI Rate signifikan mempengaruhi Inflasi dengan demikian terjadi Kausalitas Searah antara Variabel BI Rate terhadap Inflasi, BI Rate yang secara statistik signifikan mempengaruhi Inflasi dan tidak berlaku sebaliknya, pada uji Impulse Response dan Variance Decomposition, terdapat goncangan melemah pada respon suku Bunga BI Rate terhadap Inflasi tetapi terus meningkat sehingga stabil pada periode 10 pengaruh signifikan, tetapi pada Estimasi VAR setelah dianalisis bahwa Variabel signifikan .terhadap Inflasi adalah BI Rate memiliki R-Squared yang terbesar yaitu sebesar 0.122689. Uji stasionaritas BI 7 DRRR mengalami signifikan pada tingkat First different, pada uji panjang lag optimal BI 7 DRRR lebih signifikan dibandingkan BI Rate jika dibandingkan perbedaan yang lebih signifikan sehingga dalam pengujian ini lebih signifikan dengan AIC terendah adalah BI 7 DRRR. Pada uji Kausalitas Granger disimpulkan tidak terjadi kausalitas granger apapun untuk kedua variabel BI 7 DRRR pada uji Impulse Response (IRF) \& Variance Decomposition di Variabel BI 7 DRRRR yang lebih stabil mempengaruhi inflasi melihat pergerakkan tidak terlalu cenderung negaatif dan terus menurun. Bank Indonesia akan akan menaikkan suku bunganya apabila merasa jumlah uang yang beredar dimasyarakat dapat memicu inflasi, hal tersebut dilakukan guna mengendalikan peredaran uang tersebut.Hasil penelitiaan mendukung teori ini bahwa suku bunga berpengaruh positif dan signifikan terhadap jumlah uang beredar dari (Aprileven (2015) , Rytia dan Nyoman (2018).

\section{KESIMPULAN DAN SARAN}

\section{Kesimpulan}

Berdasarkan hasil analisis data mengenai pengaruh BI Rate dan BI 7 Day Reverse Repo Rate terhadap inflasi periode Januari 2014 - Februari 2019 dapat disimpulkan bahwa Suku Bunga acuan BI Rate berpengaruh positif secara signifikan terhadap inflasi hal ini dibuktikan dengan diperolehnya tahapan Uji Var dimana variabel hasil olahan data kurang dari $0,05 \%$ artinya variabel BI Rate berperan efektif dalam meredam inflasi. Hasil dari analisis bahwa BI Rate signifikan pada uji alat analisis VAR. Dalam menguji efektivitas BI Rate, sebagai sasaran akhir kebijakan moneter memiliki kestasioneritasan terhadap Inflasi, Suku bunga acuan BI 7 Day Reverse Repo Rate berdasarkan hasil olahan data berpengaruh positif terhadap inflasi tetapi pada tahapan Uji Var tidak signifikan karena melewati batas tolak ukur sebesar 0,05\%, dan di bandingkan dengan suku BI rate R-square signifikan Dalam menguji efektivitas.

\section{Saran}

Bank Indonesia sebagai bank sentral diharapkan berhati-hati ketika mengeluarkan kebijakan dalam menaikkan tingkat suku bunga dan tetap memperhatikan laju inflasi yang telah ditetapkan.Hal ini, guna memenuhi tujuan utama dari Bank Indonesia yakni mencapai 
dan memelihara nilai Rupiah yang stabil untuk mendorong pertumbuhan ekonomi yang berkualitas.

\section{DAFTAR PUSTAKA}

Andrianus, Fery; \& Niko,Amelia. (2006). Analisis faktor-faktor yang mempengaruhi inflasi di Indonesia Periode 1997;3-2005, Jurnal Ekonomi Pembangunan,6(2), 173-186

Aprileven, Harda Putra. (2015). Pengaruh faktor-faktor ekonomi terhadap inflasi di Indonesia yang dimediasi oleh jumlah uang beredar Jurnal Ekonomi Pembangunan. Economics Development Analysis Journal 3(3),169-179

Balafif. M. Mamak. (2007). Faktor-faktor yang mempengaruhi inflasi di Indonesia. Jurnal Ekonomi Pembangunan, Dialektika 5.(1),119-129

Bank Indonesia. (2009). Beberapa edisi. Laporan Tahunan Bank Indonesia. Buletin Moneter dan Perbankan: Jakarta

Brodjonegoro, Hamza. (2008). Modul ekonometrik I. Erlanga : Jakarta

Brzezina, M. Bezoza. (2001). The realitionship between interest rates and inflation. Economics Development Analysis Journal 4 (1),168-187

Gul, Ekrem; \& Ekinci, Aykut. (2006). The causal relationship between nominal interest rates and inflasion. Administrative Development Journal 4 (.54), Hal 69 - 96

Hasibuan,LS; R Nurjanah; \& E Umiyati. (2019). Faktor-faktor yang mempengaruhi inflasi Provinsi-Provinsi di Sumatera, e-Jurnal Perspektif Ekonomi dan Pembangunan Daerah 8 (1), 1-14

Hastuti.D; M.Edhie,Purnawan;\& S.Sunargo. (2018). Pengaruh variabel-variabel di sektor riil dan perbankan terhadap Shock Credit Default Swap (CDS) di Indonesia, $e$ Journal Perdagangan Industri dan Moneter, 6(2), 62-80

Mankiw, N. Gregory. (2006). Pengantar ekonomi makro, Edisi Tiga, Terjemahan. Jakarta: Salemba empat.

Noviantoro, B; E Emilia; \& YV Amzar. (2017).Pengaruh harga CPO, harga minyak mentah dunia, harga karet dunia dan kurs terhadap defisit neraca transaksi berjalan Indonesia, Jurnal Paradigma Ekonomika, 12 (1), 31-40

Rytia Fajarati; \& Nyoman Djinar. (2018). Analisis dampak kebijakan moneter terhadap jumlah uang beredar, cadangan devisa dan laju inflasi di Indonesia Tahun 20102016. Jurnal Ekonomi Pembangunan Universitas Udayana, (S.1), p.1168-1198, may 2018. ISSN 2303-0178. 4 ( 64 ), 54- 65

Sukirno, Sadono.( 2004). Makro ekonomi, Teori Pengantar: PT Raja Grafindo Persada. Jakarta 